\title{
Announcement
}

\section{PROTECTION OF LIFE IN THE SEA}

This topic will be the focal point of the

\section{4th EUROPEAN MARINE BIOLOGY SYMPOSIUM (International Helgoland Symposium 1979)}

to be held from September 23 (arrival) to september 29 (departure), 1979, on the Island of Helgoland (Federal Republic of Germany). Sponsored by the Biologische Anstalt Helgoland (BAH), the symposium is intended to serve as an international, interdisciplinary platform for presenting and discussing important information on:

(1) Threats from Major Sources of Sea-water Pollution

(2) Management of Areas, Species, and Ecosystems.

Specific problems will be considered in depth in two Informal Sessions:

(A) Methods for Assessing Pollution Effects

(B) Ocean Management: How can we Proceed?

You are invited to submit a paper to be considered for presentation (allotted time: $20 \mathrm{~min}+10 \mathrm{~min}$ for discussion). Paper acceptance is based on abstracts. These should be at the Symposium office no later than May 31, 1979. .

For further details write to Symposium office:

Biologische Anstalt Helgoland

Palmaille 9

D-2000 Hamburg 50

Federal Republic of Germany

Prof. Dr. O. Kinne

Director, $\mathrm{BAH}$ 